\title{
Association Study of Angiotensin-Converting Enzyme Ins/Del Polymorphism with Hypertension in Punjabi Population
}

\author{
N.K. Randhawa, A. Kumar, K. Matharoo and A.J.S. Bhanwer* \\ Department of Human Genetics, Guru Nanak Dev University, Amritsar 143 005, Punjab, India
}

KEYWORDS ACE; Hypertension; I/D polymorphism

\begin{abstract}
Angiotensin-converting enzyme (ACE) is the key enzyme of the Renin-angiotensin system (RAS) which maintains the blood pressure homeostasis in our body. The association of the ACE insertion (I) or deletion (D) with essential hypertension has been demonstrated by many studies. The present study is aimed to determine the association, if any, of ACE I/D polymorphism with essential hypertension in Punjabi population. The ACE I/D polymorphism genotype frequencies were calculated by comparing essential hypertensive patients with ethnically similar normotensive controls. The samples were collected from the outpatient departments of various hospitals of Punjab. The subjects who had systolic blood pressure (SBP) of $140 \mathrm{mmHg}$ or greater, and diastolic blood pressure (DBP) of $90 \mathrm{mmHg}$ or greater, or were using any antihypertensive medication were considered as hypertensive. The DNA samples from the patients (100) and controls (100) were isolated, amplified by PCR and analyzed on agarose gel. When all the genotypes were compared in patients and controls, the chi square value was 0.444 , which was not significant at 5\% level. The age, height and weight were analyzed in the three different categories DD, ID, II which did not show any significant relationship with the disease. A consistent increase was seen in the SBP and DBP in all the three genotypes from DD, ID to II respectively. This increase was statistically significant for DBP especially in case of DD vs II at $5 \%$ level $(\mathrm{t}=2.34, \mathrm{p}<0.05)$
\end{abstract}

\section{INTRODUCTION}

Hypertension is a major risk factor for cardiovascular disease both in the developed and developing countries. It is estimated that by 2020 the burden of cardiovascular disease in India would surpass any other country in world (Gupta et al. 2004). There are various environmental, genetic and physiological factors that affect hypertension.

Renin-angiotensin system (RAS) in the body is a hormone pathway to regulate the blood pressure and blood volume in the body (Inagami 1994). Angiotensin-I converting enzyme (ACE) is a key enzyme of the system which activates the angiotensin-I (decapeptide) by cleaving it into angiotensin II (octapeptide) which is a potent vasoconstrictor and inactivates the vasodilator peptide bradikinin (Richard et al. 2004; Turner et al. 2000).

Most of the association studies are based on the insertion or deletion of the $287 \mathrm{bp}$ Alu repeat in the intron 16 of the gene, in which D allele is found to be associated with an increase in the

*Corresponding Author: Dr. A.J.S. Bhanwer, Professor Department of Human Genetics, Guru Nanak Dev University, Amritsar, 143005, Punjab, India Telephone: 0183-2258802-09 Extn. 3278.

Fax: 0183-2258819, 2258820.

E-mail: ajsbhanwer@yahoo.com plasma ACE levels in a codominant fashion (Rigat et al 1990). Several studies have reported the association of the ACE I/D polymorphism and its susceptibility to hypertension (Zee et al. 1990; Morise et al. 1994). However, it is noticed that these results have not been replicated in certain other studies (Chiang et al. 1997; Kiema et al.1997). It has also been reported that the increase in the blood pressure is gender specific and association is stronger in men than in women (O'Donnell et al. 1998).

It is true that blood pressure is also influenced by the interaction of genetic and some environmental factors, but the detection of statistically significant relationship between the ACE I/D polymorphism and various other environmental factors has received less than required attention. Such interactions can give rise to differences in the genotypic and phenotypic variations in different environments.

Keeping all the above factors in mind, the present case control study was designed to see the association, if any, of the ACE I/D polymorphism with hypertension and to evaluate the effect of various other parameters like age, height and weight on essential hypertension in the population of Punjab.

\section{MATERIAL AND METHODS}

Study sample: In the present investigation 
blood samples of 100 hypertensive patients and 100 samples of age, sex and caste matched normal, healthy individuals as control group were collected in tubes containing 0.5M EDTA as an anticoagulant. The samples were transported on ice to the laboratory and stored at $-20^{\circ} \mathrm{C}$ till further analysis. All the patient samples were collected from the outpatient departments of various hospitals of Punjab and control samples were collected from normal healthy population after obtaining the informed consent. Various parameters like age, height, weight, smoking habits and dietary patterns were recorded in a questionnaire.

The samples, of only those patients were included in the study who were classified as hypertensive, according to the criterion of JNC VII i.e. who had systolic blood pressure (SBP) of $140 \mathrm{mmHg}$ or greater, and diastolic blood pressure (DBP) of $90 \mathrm{mmHg}$ or greater, or were using any anti- hypertensive medication.

$A C E$ Insertion/deletion Genotyping: The genomic DNA was isolated using standard protocol (Gill et al. 1987). The quality of DNA was checked by $1 \%$ agarose gel electrophoresis and the quantity was determined by spectrophotometric analysis. Amplification of the isolated DNA was achieved using standard polymerase chain reaction (PCR) with the following primers, 5'-CTG GAG AGC CAC TCC CAT CCT TTC T-3' and 5'-GAC GTG GCC ATC ACA TTC GTC AGA T-3'( Tiret et al. 1992). In a total reaction volume of $10 \mu \mathrm{l}, 100 \mathrm{ng}$ of genomic DNA was used along with $50 \mu \mathrm{M}$ of each of dNTPs, $10 \mu \mathrm{M}$ Tris- $\mathrm{HCl}$ (pH 9.0), $1.5 \mu \mathrm{M} \mathrm{MgCl}_{2}$, $50 \mu \mathrm{M} \mathrm{KCl}, 0.01 \%$ gelatin, $0.13 \mu \mathrm{M}$ of each primer and 0.25 units of Taq polymerase (Bangalore Genei, Bangalore). The initial denaturation at $95^{\circ} \mathrm{C}$ for 5 minutes was followed by thirty-five cycles of denaturation at $95^{\circ} \mathrm{C}$ for $45 \mathrm{sec}$, annealing at $56^{\circ} \mathrm{C}$ for $45 \mathrm{sec}$ and extension at $72^{\circ} \mathrm{C}$ for $45 \mathrm{sec}$. The final extension was carried out at $72^{\circ} \mathrm{C}$ for 10 minutes. The products, thus obtained, were then electrophoresed on 2\% agarose gel and the results were seen by ethidium bromide staining on UV transilluminator.

Statistical Analysis: Data analysis was done with the help of an SPSS version 7.5. The genotypes were analyzed using chi-square analysis using 3X2 tables. Means were compared by using one-way ANOVA and the SBP and DBP in the patients were compared by t- test.

\section{RESULTS}

As no reports are available regarding the association between ACE I/D polymorphism and hypertension in the population of Punjab, so the present case control study examined the possible association of ACE I/D polymorphism in the hypertensive Punjabi population

The patient group comprised of 40 males and 60 females. The mean age of the patients was $52.85 \pm 11.64$ and the mean height and weight of this group was $160.45 \pm 17.75($ mean \pm SD) and $69.6 \pm 11.83$ respectively. $14 \%$ of patients were smokers and $35 \%$ of the patients were taking nonvegetarian diet (Table 1).

In the control group there were 60 females and 40 males. The mean age of the group was $50.7 \pm 10.07$ whereas the mean height and weight were $162.27 \pm 7.74$ and $64.39 \pm 10.78$ respectively. $10 \%$ of these were smokers and $45 \%$ were taking non-vegetarian diet (Table 1).

Table 2 shows the data pertaining to all the genotypes and the allele distribution in hypertensive patients and the normal healthy control group. The frequency of I/D heterozygotes as compared to homozygotes, was higher both in the patient and control group. The results were however, statistically insignificant.

We have also analyzed the association of all the three genotypes with the phenotypic variables such as age, height and weight. Means and standard deviations for all the three genotypes were calculated and these values were compared using one-way ANOVA to see if the difference in the values was significant or not. On analysis it was seen that there was no significant difference between the age, height

Table 1: Demographic characteristics of subjects.

\begin{tabular}{lcc}
\hline & Controls & Patients \\
\hline Number & 100 & 100 \\
Gender & & \\
$\quad$ Males & 40 & 40 \\
$\quad$ Females & 60 & 60 \\
Age & $50.7 \pm 10.07 *$ & $52.84 \pm 11.64$ \\
Height & $162.27 \pm 7.74$ & $160.45 \pm 17.75$ \\
Weight & $64.39 \pm 10.78$ & $69.6 \pm 11.83$ \\
Smoker & 10 & 14 \\
Non-smoker & 90 & 86 \\
Diet & & \\
$\quad$ Vegetarian & 55 & 65 \\
$\quad$ Non-vegetarian & 45 & 35 \\
\hline
\end{tabular}

$*(\mathrm{Mean} \pm \mathrm{SD})$ 
and weight in all the three genotypes (Table 3 ).

The means of SBP and DBP in the patients in the genotypes DD, ID, II showed a consistent increase, as shown in Table 4. When these blood pressures were analyzed between the genotypes using t-test the $t$ values were not significant for all the cases except the case of DBP in the DD vs II where the increase was statistically significant with $t$ value 2.34 and $\mathrm{P}<0.05$ as shown in Table 5 .

On comparing the non-vegetarians with vegetarians, the genotypic frequencies obtained amongst the patients and their respective controls were 0.229 and 0.012 which were not significant at $5 \%$ level as shown in Table 6.

\section{DISCUSSION}

It is estimated that the number of deaths in India due to cardiovascular disease would rise up to 4.6 million by the year 2020 . Hypertension is directly responsible for $57 \%$ of stroke deaths and $24 \%$ of all coronary heart disease deaths (Gupta et al. 2004). South Asians have an increased risk of heart disease in comparison to Europeans, but African Caribbeans seem to fall in low risk category (Chaturvedi et al. 2003).

The insertion/deletion polymorphism in the ACE gene is correlated with the circulating ACE levels. Individuals with II genotype have the lowest circulating ACE levels as compared to DD genotype, which are known to have high ACE levels (Samani et al. 1994). A significant association of the ACE D allele with hypertension in African Americans, Chinese and Japanese population has already been established (Duru et al. 1994; Chiang et al. 1996; Morise et al. 1994; Nakno et al. 1998). On the other hand some studies show that I allele is associated with hypertension in the Australian and Pakistani populations (Zee

Table 2: Distribution of ACE I/D genotypes and allele frequencies in hypertensive patients and normal healthy subjects.

\begin{tabular}{lcccccc}
\hline Population ( $)$ & \multicolumn{3}{c}{ Genotype frequencies (Percentage) } & & \multicolumn{2}{c}{ Allele frequencies } \\
\cline { 2 - 3 } & $D D$ & ID & II & & allele & I allele \\
\hline Hypertensive group (100) & $17(17.0 \%)$ & $58(58.0 \%)$ & $25(25.0 \%)$ & & 0.46 & 0.54 \\
Control group (100) & $14(14.0 \%)$ & $62(62.0 \%)$ & $24(24.0 \%)$ & & 0.45 & 0.55 \\
\hline
\end{tabular}

$\chi^{2}$-value 0.444 not significant at $5 \%$ level.

Table 3: Age, height and weight values according to ACE I/D polymorphism in the overall sample population of the study.

\begin{tabular}{lccrc}
\hline Variable & $D D$ & $I D$ & $I I$ & $* F$ values \\
\hline Age & $46.83 \pm 11.53^{* *}$ & $50.5 \pm 11.58$ & $52.75 \pm 9.84$ & 2.596 \\
Height & $162.07 \pm 7.74$ & $161.23 \pm 16.9$ & $165.25 \pm 8.48$ & 1.374 \\
Weight & $67.30 \pm 10.59$ & $66.14 \pm 12.29$ & $66.92 \pm 11.54$ & 0.079 \\
\hline
\end{tabular}

*F values calculated by one-way ANOVA

$* *($ Means $\pm \mathrm{SD})$

Table 4: Systolic blood pressure (SBP) and diastolic blood pressure (DBP) according to the genotypes of the patients

\begin{tabular}{lccc}
\hline Genotype & Number & \multicolumn{1}{c}{ SBP } & \multicolumn{1}{c}{ DBP } \\
\hline DD & 17 & $145.49 \pm 21.9^{*}$ & $89.18 \pm 9.4$ \\
ID & 58 & $149.95 \pm 16.74$ & $94.71 \pm 11.43$ \\
II & 25 & $153.44 \pm 20.53$ & $96.84 \pm 10.57$ \\
\hline
\end{tabular}

Table 5: Comparison of SBP and DBP between the Genotypes calculated by t-test.

\begin{tabular}{lll}
\hline Genotype & $S B P$ & $D B P$ \\
\hline DD Vs ID & 0.795 & 1.8 \\
DD Vs II & 1.1 & $2.34^{*}$ \\
ID Vs II & 0.9 & 0.78 \\
\hline
\end{tabular}

*Significant at $5 \%$ level $(\mathrm{P}<0.05)$

Table 6: Comparison of diet patterns in the hypertensive patients and normal healthy controls.

\begin{tabular}{|c|c|c|c|c|c|c|c|c|}
\hline \multirow[t]{2}{*}{ Population } & \multicolumn{4}{|c|}{ Non-vegetarians } & \multicolumn{4}{|c|}{ Vegetarians } \\
\hline & $D D$ & $I D$ & $I I$ & $\chi^{2}$ & $D D$ & $I D$ & $I I$ & $\chi^{2}$ \\
\hline $\begin{array}{l}\text { Hypertensive group (100) } \\
\text { Control group (100) }\end{array}$ & $\begin{array}{r}7 \\
11\end{array}$ & $\begin{array}{l}22 \\
27\end{array}$ & $\begin{array}{l}6 \\
7\end{array}$ & $0.229 *$ & $\begin{array}{r}9 \\
31\end{array}$ & $\begin{array}{l}37 \\
16\end{array}$ & $\begin{array}{r}19 \\
8\end{array}$ & $0.012 *$ \\
\hline
\end{tabular}


et al. 1992; Ismail et al. 2004). The association of I allele with hypertension in Pakistani population may be attributed to the presence of high levels of inbreeding, thereby resulting in higher heterozygosity. The heterogeneity in association of ACE I/D polymorphism with essential hypertension may be either due to varied ethnicity (Barley et al.1994) or the various other genetic and environmental factors implicated in the regulation of blood pressure (Guyton et al. 1981). Any variation in even a single etiological factor could lead to difference in blood pressure and thereby hypertension.

The present investigation was also influenced by the fact of positive association of ACE gene with the Pakistani population which inhabits and seems to have arisen from almost same geographical area and exhibits almost same cultural practices too.

A number of studies conducted worldwide document no association of the ACE I/D polymorphism with the essential hypertension (Pamies et al. 1999; Dazida et al. 2001; Mondry et al. 2005). Similarly, our data did not show any association between the ACE I/D polymorphism and essential hypertension. The chi-square values were not significant. On analyzing the data it was observed that the incidence of hypertension was greater in women than in men. There was no significant association of the age, height and weight with the essential hypertension. There was a consistent difference in the means of SBP and DBP in the DD, ID, and II genotypes. The results after further analysis have shown that DBP in DD vs II group increased significantly. This predicts that the patients with II genotype had high diastolic blood pressures as compared to those with genotype DD.

When the dietary factor was taken into account, no significant correlation between the diet pattern and hypertension could be established. However, the overall dietary habit of Punjabis is to have high cholesterol containing diet, which could be a predisposing factor towards hypertension.

Our study is the first of its kind to evaluate ACE I/D polymorphism for its association with essential hypertension. The presence of sizeable number of heterozygotes $(58 \%)$ within this population makes it highly susceptible to hypertension and therefore makes our findings significant. The sample size of the study was relatively small and therefore an extensive survey is now imperative to confirm the findings.

\section{REFERENCES}

Barley J, Blackwood A, Cartere ND, Crew DE, Cruickshank JK, Jeffreys S, Ogunlesi AO, Segnella GA 1994. Angiotensin Converting Enzyme Insertion/Deletion Polymorphism: Association with Ethnic Group. J Hypertens, 12: 955-957.

Chaturvedi N 2003. Ethnic Differences in Cardiovascular Disease. Heart, 89: 681-686.

Chiang FT, Chern TH, Lai ZP, Tseng CD, Hsu KL, Lo HM, Tseng YZ 1996. Age and Gender Dependent Association of the Angiotensin-Converting Enzyme Gene with the Essential Hypertension in a Chinese Population. J Hum Hypertens, 10: 823-826.

Dazida G, Sobstyl J, Puzniak A, Golon P, Mosiewicz J, Hanzlik J 2001. Polymorphisms of AngiotensinConverting Enzyme and Angiotensin II Receptor Type 1 Gene in Essential Hypertension in Polish Population. Clin Research, 7: 1236-1241.

Duru K, Farrow S, Wang J, Lockbetteb W, Kurtz T 1994. Frequency Of Deletion Polymorphism in the Gene for Angiotensin Converting Enzyme is Increased In African-Americans With Hypertension. Am J Hypertens, 7: 759-762.

Gill P, Lygo JE, Fowler SJ 1987. An Evaluation of DNA Fingerprinting for Forensic Purposes. Electrophoresis, 8: 38-44.

Gupta R 2004. Trends in Hypertension Epidemiology in India. Hum Hypertens, 18: 73-78.

Guyton AC, Hall JE, Lohmeier TE, Kastner PR 1981. Blood Pressure Regulation: Basic Concepts. Fed Proc, 40: 2252-2256.

Inagami T 1994. The Renin Angiotensin System. Assays Biochem, 28: 147-164.

Ismail M, Akhter N, Nasir M, Firesat S, Ayub Q, Khaliq S 2004. Association between the Angiotensin Converting Enzyme Gene Insertion/Deletion Polymorphism and Essential Hypertension in Young Pakistani Patients. J Biochem Mol Bio, 35: 252-255.

JNC-VII 2004. The Seventh Report of Joint National Committee on Prevention, Detection, Evaluation and Treatment of High Blood Pressure. National Institute of Health; National Heart Lung Blood Institute; National High Blood Pressure Education Programme.

Kieme T, Kauma H, Rantala A, Lilja M, Reunanen A, Kesaniemi Y, Savolainen M 1996. Variation at the Angiotensin-Converting Enzyme Gene and Angiotensinogen Gene Loci in Relation to Blood Pressure. Hypertens, 28:1070-1075.

Mondry A, Loh M, Liu P, Zhu AL, Nagel M 2005. Polymorphism of Insertion/Deletion ACE And M235T AGT Genes in Hypertension: Surprising New Findings and Mata-Analysis of Data. BMC Nephrol, 11 6:1.

Morise T, Takeguchi Y, Takeda R 1994. Angiotensin Converting Enzyme Polymorphism and Essential Hypertension. Lancet, 343: 125.

Nakno Y, Oshima T, Hiraga H, Matsuure H, Kajiyama G, Kambe M 1998. Genotype of Angiotensin IConverting Enzyme Gene is a Risk Factor for Early Onset of Essential Hypertension in Japanese Population. J Lab Clin Med, 131: 502-506. 
O'Donnell C, Lindpaintner K, Larson M, Rao V, Ordivas J, Schaefer E, Myers R, Levy D 1998. Evidence for Association and Genetics Linkage of the AngitensinConverting Enzyme Locus with Hypertension and Blood Pressure in Men But not in Women in the Framingham Heart Study. Circulation, 97: 17661772 .

Pamies AE, Palmero PC, Garcia LR, Stiefel GJP, Miranda GML, Martin SV, Villar OJ, Nunez RA, Carnealdo FJ 1999. Effect of Angiotensinogen M235T and the Angiotensin-Converting Enzyme I/D Polymorphisms on Arterial Hypertension and Other Cardiovascular Risk Factors. Med Clin, 113(5): 164168.

Richard NR 2004. Tissue Rennin-Angitensin System. Med Clin N Am, 88: 19-38.

Rigat B, Hubert C, Alhenc-Gelas F, Corvol P, Soubrier F 1990. An Insertion/Deletion Polymorphism in the Angiotensin I-Converting Enzyme Gene Accounting for Half the Variance of Serum Enzyme Levels. $J$
Clin Invest, 86: 1343-1346

Samani NJ, Thompson JR, Otoole L, Channer K, Woods KL 1994. A Meta-Analysis of the Association of the Deletion Allele of the Angiotensin-Converting Enzyme Gene with Myocardial Infarction. Circulation, 94: 708-712.

Tiret L, Right B, Visvikis S, Breda C, Corvol P, Cambien F, Soubrier F 1992. Evidence from Combined Segregation and Linkage Analysis that a Variant of Angiotensin I Converting Enzyme (ACE) Gene Control Plasma ACE Levels. Am J Hum Genet, 51: 197-205

Turner AJ, Hopper NM 2002. The AngiotensinConverting Enzyme Gene Family: Genomics and Pharmacology. Trends Pharmaco Sci, 23: 177-183.

Zee RY, Lou YK, Griffiths LR, Morrise BJ 1992. Association of a Polymorphism of Angiotensin IConverting Enzyme Gene with Essential Hypertension. Biochem Biophys Res Commun, 184: 9-15. 